NBER WORKING PAPER SERIES

\title{
FOREIGN DIRECT INVESTMENT AND THE OPERATIONS OF MULTINATIONAL FIRMS: CONCEPTS, HISTORY, AND DATA
}

\author{
Robert E. Lipsey \\ Working Paper 8665 \\ http://www.nber.org/papers/w8665 \\ NATIONAL BUREAU OF ECONOMIC RESEARCH \\ 1050 Massachusetts Avenue \\ Cambridge, MA 02138 \\ December 2001
}

This paper was prepared for the Handbook of International Trade, edited by James Harrigan, to be published by Blackwell. I am indebted for comments and suggestions to James Harrigan and other members of the National Bureau's International Trade and Investment program and to Ned Howenstine and Obie Whichard of the Bureau of Economic Analysis of the U.S. Department of Commerce. The views expressed herein are those of the author and not necessarily those of the National Bureau of Economic Research.

(C) 2001 by Robert E. Lipsey. All rights reserved. Short sections of text, not to exceed two paragraphs, may be quoted without explicit permission provided that full credit, including (C) notice, is given to the source. 
Foreign Direct Investment and the Operations of Multinational Firms:

Concepts, History, and Data

Robert E. Lipsey

NBER Working Paper No. 8665

December 2001

JEL No. F21, F23

\begin{abstract}
The concept and measurement of foreign direct investment have changed over time, and what is measured by balance of payments flows and stocks is quite different from what is implied by theories of direct investment. The industrial distribution of stocks of FDI, the most widely available measure, is only poorly related to the distribution of FDI production, and changes in stocks are poorly related to changes in production.

FDI flows have grown in importance relative to other forms of international capital flows, and the resulting production has increased as a share of world output, but it was still only about 8 per cent at the end of the 20th Century. The United States began its role as a foreign direct investor in the late 19th Century, while it was still a net importer of capital. It became the dominant supplier of direct investment to the rest of the world, accounting for about half of the world's stock in 1960. Since then, other countries have become major direct investors. The U.S. share is now less than a quarter of the world total and the United States has become a major recipient of FDI from other countries.
\end{abstract}

Robert E. Lipsey

National Bureau of Economic Research

365 Fifth Avenue, 5th Floor, Suite 5318

New York, NY 10016-4309

(212) 817-7961

rlipsey@gc.cuny.edu 


\section{Introduction}

The term "Foreign Direct Investment," or "FDI," encompasses two related but different sets of topics or activities, explained by different theories and by different branches of economics. The first might be referred to as the international finance, or macro, view. The second might be referred to as the industrial organization, or micro, view.

The macro view sees FDI as a particular form of the flow of capital across national borders, from home countries to host countries, measured in Balance of Payments Statistics. Those flows give rise to a particular form of stocks of capital in host countries, namely the value of home country investment in entities, typically corporations, controlled by a home country owner, or in which a home country owner holds a certain share of voting rights. The variables of interest are the flow of financial capital, the value of the stock of capital that is accumulated by the investing firms, and the flows of income from the investments.

The micro view tries to explain the motivations for investment in controlled foreign operations, from the viewpoint of the investor. It also examines the consequences to the investor, and to home and host countries, of the operations of the multinationals or of the affiliates created by these investments, rather than the size of the flows or the value of the investment stocks or investment position. These consequences arise from their trade, employment, production, and their flows and stocks of intellectual capital, unmeasured by the capital flows and stocks in the balance of payments, although some proxies for the flow of intellectual capital are part of the current account. These motivations and consequences are intrinsically related to the investing firms' control of the affiliates and the ability of the multinationals to coordinate the activities of parents and affiliates. 
The micro view is the older one, preceding interest in direct investment as a form of capital flow. It was reflected in concerns about the consequences of foreign control for the host economy, represented by book titles such as The American Invaders, (1901), or The American Invasion (1902), two of the earliest titles listed by Wilkins (1970). It was also reflected in one of the earliest research studies of U.S. direct investment, which attempted to explain the motivations behind firms' expansion into foreign countries (Southard, 1931).

\section{Concepts of Foreign Direct Investment}

\section{What is a Foreign Direct Investment Entity?}

Firms and individuals have many different possible ways of holding assets in foreign countries. Which of these are considered direct investment and which firms are considered multinational enterprises depends on the definition of a "foreign direct investment entity".

What constitutes a foreign direct investment entity has been defined differently for balance of payments purposes and for studies of firm behavior. It has also been defined in different ways by different countries and the definition has changed over time. The definition of foreign direct investment as a capital flow and a capital stock has changed correspondingly.

The dominant current definition of a direct investment entity, prescribed for balance-ofpayments compilations by the International Monetary Fund (1993), and endorsed by the OECD (1996), avoids the notion of control by the investor in favor of a much vaguer concept. "Direct investment is the category of international investment that reflects the objective of a resident entity in one economy obtaining a lasting interest in an enterprise resident in another economy. (The resident entity is the direct investor and the enterprise is the direct investment enterprise). The lasting interest implies the existence of a long-term relationship between the direct investor 
and the enterprise and a significant degree of influence by the investor on the management of the enterprise" (IMF,1993, p 86).

While the concept is vague, the recommended implementation is specific. " ... a direct investment enterprise is defined in this Manual as an incorporated or unincorporated enterprise in which a direct investor, who is resident in another economy, owns $10 \%$ or more of the ordinary shares or voting power (for an incorporated enterprise) or the equivalent (for an unincorporated enterprise) (IMF, 1993, p. 86).

The IMF definition is governing for balance-of-payments compilations, but there is a different, but related, concept and a different official definition in the United Nations System of National Accounts, the rule book for compiling national income and product accounts, that retains the idea of control, and reflects the micro view more. In these accounts, which measure production, consumption, and investment, rather than the details of capital flows, there is a definition of "foreign-controlled resident corporations." Foreign-controlled enterprises include subsidiaries more than $50 \%$ owned by a foreign parent. "Associates" of which foreign ownership of equity is $10-50 \%$, “...may be included or excluded by individual countries according to their qualitative assessment of foreign control...” (Inter-Secretariat Working Group on National Accounts, 1993, pp. 340-341). Thus, from the viewpoint of a host country, and for analyzing production, trade, and employment, control remains the preferred concept.

In the United States, the first official survey of outward direct investment, conducted by the U.S. Department of Commerce for the end of 1929, sought to measure “...the amount of capital involved in the extension of American enterprise into foreign countries..." (U.S. Department of Commerce, 1930, p. 1). In that survey, 'Foreign 'direct investments,' as herein considered, include those commercial and industrial properties situated abroad and belonging to 
residents of the United States and its Territories, from which a return is normally expected. They are called 'direct investments' to distinguish them from 'portfolio investments' acquired through the purchase of foreign securities publicly offered and through the international securities movement; by definition, therefore, pure 'interest capital' and capital that moves incidental to a migration of labor are, in large part, excluded. Investments of the 'portfolio' type are included when they are a part of the holding of American commercial and industrial corporations. Pure 'interest' capital is included when invested in American-controlled corporations operating abroad" (ibid), pp. 1-2). The survey asked U.S. companies for the value of “...investments in lands, buildings, factories, public utilities, warehouses, shops, stocks of goods, wharves, marine equipment, and other property in foreign countries... that are owned in whole or in part by your company or by an affiliated or subsidiary corporation." (ㅎid, p. 51).

The next survey, for 1936, again emphasized the interest in "the international extensions of American business enterprise" ( U.S. Department of Commerce, 1938, p.2). The control aspect of the definition was made more explicit, referring to "...those foreign corporations or enterprises which are controlled by a person or small group of persons (corporate or natural) domiciled in the United States, or in which such person or group has an important voice ....The factor of control has been purposely emphasized in the definition, since it is considered to be the most significant basis for classifying investments. However, no hard and fast quantitative measurement of control has been devised. Minority interests have been included in these data in considerable number and volume. The reason, of course, is that the degree of control is not measured exactly by the percentage of common stock held. In no case has an investment holding of less than $10 \%$ been included in this category, and interests of less than $20 \%$ are few in number and small in value..." (ibid, pp. 2-3). It was later emphasized that using a $50 \%$ criterion 
“...would be to miss its qualitative aspect...the quantitative basis fails to measure accurately the vital ties and connections between American and foreign corporations. The qualitative measure may also lead one into some errors because it is difficult to gage the force of character and leadership of the individuals associated with the enterprises..." (ibid, p. 45).

The outward survey for 1950 ( U.S. Department of Commerce, 1953) provided a more precise definition, covering four categories of FDI:

1. "Foreign corporations, the voting securities of which were owned to the extent of $25 \%$ or more by persons or groups of affiliated persons, ordinarily resident in the United States."

2. "Foreign corporations, the voting stock of which was publicly held within the United States to an aggregate of $50 \%$ or more, but distributed among stockholders, so that no investor, or group of affiliated investors, owned as much as $25 \%$."

3. "Sole proprietorships, partnerships, or real property (other than property held for the personal use of the owner) held abroad by residents of the United States."

4. "Foreign branches of United States corporations."

By this time the Department had moved away from criteria requiring judgments as to degree of control toward those that could be implemented mechanically, perhaps because the number of firms involved had become too large for handicraft judgments. However, the idea behind the definition still stressed control and the thought that control was a determinant of behavior.

In recent years, the U.S. Department of Commerce has followed what are now the IMF guidelines. The latest inward direct investment benchmark survey defines direct investment in those terms and uses the $10 \%$ criterion. In contrast to the 1950 rules, the survey publication states that "Direct investment refers to ownership by a single person, not to the combined 
ownership of all the persons in a country" (U.S. Department of Commerce, 2001, p. M-4). However, "person" is fairly broadly defined, to encompass various types of organizations and even "associated groups." The latter are "...two or more persons who exercise their voting privileges in a concerted manner - by the appearance of their actions, by agreement, or by an understanding - in order to influence the management of a business enterprise ( $\underline{\text { idem }}$. Thus, a little leeway seems to be left for the collectors of data, beyond the $10 \%$ criterion, to interpret the idea of influence.

The abandonment of the idea of control is not the only respect in which the measures of direct investment depart from the theoretical models of the phenomenon. A single "direct investment enterprise" can be part of several different multinational firms, possibly from several countries. Duplication is avoided in investment flow and stock data by allocating the financial aggregates of an affiliate to the various owners according to the extent of their ownership. In this respect, the concerns of the producers of the balance of payments have come to outweigh those of the analysts of firm behavior.

Another respect in which this seems to be the case, again related to balance-of-payments definitions, is that the residence of a transactor, rather than of the ultimate owner, determines its nationality. Thus, a firm incorporated in the United States that owns an affiliate or affiliates outside the country, is classified as a U.S. parent company even if it is controlled by a foreign firm. For that reason, a U.S. firm could be identified as both a U.S. parent and a U.S. affiliate of a foreign firm. In 1994, U.S. parents “...that were ultimately controlled by a foreign parents accounted for ...11\% of the assets and for $14 \%$ of the sales of all U.S. parents (U.S. Department of Commerce, 1998a, p. M-7, footnote 8). If nationality is a determinant of firm behavior or, probably more important, if status as a parent rather than an affiliate is a determinant of behavior, 
this treatment may blur the analysis of U.S. parent activities and of the activities of foreign affiliates of U.S. firms.

The ownership that defines the scope of a direct investment relationship includes indirect as well as direct ownership. Direct investment enterprises include branches of a parent investor, subsidiaries, defined as incorporated enterprises more than $50 \%$ owned by the direct investor, and associates, defined as incorporated enterprises owned 10-50\%. A subsidiary or associate of a subsidiary is a direct investment enterprise of the parent, as is a subsidiary of an associate, even though the parent's interest could be below $10 \%$. An associate of an associate is not part of the parent's direct investment enterprise, although it is part of the first tier associate's enterprise (IMF, 1995, pp. 150-151). The United States requires direct and indirect ownership adding up to at least 10 per cent (U.S. Department of Commerce, 1998a, Form BE-10B(LF)).

One type of direct investment enterprise that creates problems with the interpretation of FDI data is what are called, in the Balance of Payments Manual, Special Purpose Entities, or SPEs. They include such categories as “...holding company, base company, regional headquarters ..." and have as their function "... administration, management of foreign exchange risk, facilitation of financing of investments..." and their transactions are treated in the same way as those of other direct investment enterprises, with one exception. “...for SPEs created with a sole purpose of serving in a financial intermediary capacity ...transactions recorded under direct investment are limited to those associated with permanent debt and equity (IMF 1993, p. 87). Some implications of different treatments of SPEs are described later in the section on FDI flows. 
Scholars studying multinational firms, rather than flows of capital, have set out more confined definitions. The early Harvard studies, under the direction of Raymond Vernon, confined their research to firms listed among the 500 largest U.S. corporations among which “... the U.S. parent system held equity interests in manufacturing enterprises located in 6 or more foreign countries, such equity interest in each case amounting to $25 \%$ or more of the total equity (Vaupel and Curhan, 1969, p. 3). Mira Wilkins (1970) defined "American multinational enterprise" as "the U.S. headquartered company that does business in two or more foreign countries," and a "genuine" multinational manufacturing corporation as one that "...had direct investments in more than just sales abroad, that adapted to and respected foreign local traditions, and acted under foreign rules and regulations in the nations abroad where they operated" (p. ix).

Scholarly discomfort with the treatment of direct investment flows as capital flows goes back a long time. Kindleberger (1969), in his lectures on U.S. multinationals, started out by saying that "Direct investment used to be thought of by economists as an international capital movement....But economists trying to interpret direct investment as a capital movement were struck by several peculiar phenomena. In the first place, investors often failed to take money with them when they went abroad to take control of a company; instead they would borrow in the local market. Capital movement would take place gross...but not net. Or the investment would take place in kind, through the exchange of property-patents, technology, or machineryagainst equity claims, without the normal transfer of funds through the foreign exchange associated with capital movements....Direct investment may thus be capital movement, but it is more than that (pp.1-3). The same idea, that there was something more, was expressed by John Dunning (1970) at around the same time."...something other than money capital is (or may be) involved in international direct investment. This might simply be informal managerial or 
technical guidance; on the other hand it could incorporate the dissemination of valuable knowledge and/or entrepreneurship in the form of research and development, production technology, marketing skills, managerial expertise, and so on; none of which usually accompanies investment" (p. 4).

\section{What is a parent?}

A multinational firm consists of a parent firm and the affiliates it owns or controls. Most of the home country surveys from which we know about FDI are surveys of affiliates. Very few countries make any effort to survey their parent firms, the main exceptions being The United States, Sweden, and Japan. Surveys by host countries, usually taking the form of tagging foreign-owned establishments in their economic censuses, rarely ask anything about parent firms except their nationality. Again, the United States is an exception in that a few other questions about parents are included in the inward surveys, including the name of the parent and its industry.

The term, "parent," was used in the 1950 U.S. outward survey to describe "...the owners of a reportable interest..." in foreign-owned corporations and “...collectively, individual holders of stock which in total constituted a reportable interest," which, for individual holders in that survey, was 50 \% (U.S. Department of Commerce, 1953, p. 36). The individual holders' investments accounted for about $10 \%$ of the total. The other $90 \%$ was referred to as the value of investments by "reporters" (ibid, Appendix Table 10).

The 1966 U.S. outward investment survey was much more explicit about the domestic side of the multinationals. It was the first to include a form specifically relating to the U.S. firm involved, referring to it as the "reporter," rather than the parent firm. Information was collected on the reporter's industry, type of organization, assets, liabilities, net income, $R \& D$ expenditures, 
and natural resource exploration and development costs. The reporter was explicitly instructed to include in its answers data for "domestic subsidiaries or affiliates operating in the United States and usually part of the reporter's consolidation" (U.S. Department of Commerce, 1975, p. 243). However, no information was requested for any firm of which the reporter was a subsidiary, a serious omission that was corrected in the 1977 survey.

The 1977 U.S. outward survey elevated the role of the parent to something more like equality with that of affiliates, requiring a much fuller set of data and defining the parent more broadly and consistently from an economic point of view. Although the term 'reporter' was still used in the forms, the instructions referred explicitly referred to the "U.S. Parent." The major change in definition was to require consolidation in the parent reports. It required an incorporated U.S. parent to be "the U.S. parent corporation whose voting securities are not owned more than $50 \%$ by another U.S. corporation," and including "down each ownership chain from that U.S. corporation any U.S. corporation...whose voting securities are more than $50 \%$ owned by the U.S. corporation above it" (U.S. Department of Commerce, 1981, pp. 3-4). The problem that the change in definition was intended to solve was that the reporters in earlier surveys were sometimes U.S. corporations' holding company subsidiaries that had been created specifically to own foreign operations, but had no domestic operations of their own. Treating these as parents would give a distorted picture of the relationships between U.S. parent and foreign affiliate operations. One result of the change was that the "parents" of 1977 and later years are not comparable to the "reporters" of 1966, and comparisons of "reporter" data for 1966 with "parent" data for later years are biased.

Parents, as defined in U.S. data, are almost certainly not comparable to parents as reported in Japanese data. Consolidation of company accounts is less common in Japan than in 
the United States, and there is no way to be sure that the reporting parents are not just fragments of much larger conglomerates. The Swedish surveys, which have been collected by a private research organization, do ask for consolidated reports by parent firms. Unlike the U.S. outward investment surveys they exclude Swedish firms that are affiliates of foreign firms and also foreign investment undertaken by private individuals (Swedenborg, 1979, pp. 244-245).

\section{$\underline{\text { What is an FDI Flow? }}$}

The definition of FDI flows has changed over time as the definition of FDI enterprises has changed. One such change for the United States, for example, was the elimination from the U.S. outward direct investment universe of foreign firms with large, but diffused, ownership by U.S. citizens. That reclassification resulted in the reclassification of the investment flows to and from these firms as portfolio investment and the elimination of the retained earnings of these firms from the U.S. accounts altogether. However, when the change in definition was adopted, in 1977, it was not carried back to earlier years, so that historical flow data reflect the earlier definition of FDI.

Direct investment capital flows are made up of “... equity capital, reinvested earnings, and other capital associated with various intercompany debt transactions" (IMF, 1993, p. 87). The last category is the most troublesome, covering "...the borrowing and lending of funds including debt securities and suppliers' credits - between direct investors and subsidiaries, branches, and associates.” The latter includes “...Intercompany transactions between affiliated banks (depository institutions) and affiliated financial intermediaries (e.g.,security dealers) including SPEs with the sole purpose of serving as financial intermediaries..." However, the latter are now to be included in direct investment only if they are "... associated with permanent 
debt (loan capital representing a permanent interest) and equity (share capital) investment or, in the case of branches, fixed assets. Deposits and other claims and liabilities related to usual banking transactions of depositary institutions and claims and liabilities of other financial intermediaries are classified, as appropriate, under portfolio investment or other investment (IMF 1993, p.88). This last distinction was in recognition of the ambiguities that had developed in the division of investment between direct investment and other types.

In 1998, the BEA made a major change in the treatment of U.S, affiliates that were primarily financial intermediaries, “...established mainly to facilitate the foreign securities and financing businesses of their U.S. parents or to facilitate foreign borrowing by their U.S. parents...." The capital flows associated with these activities were "...sizable and volatile." No lasting interest or desire to influence the management of an enterprise was involved in these transactions and it was decided that they should be treated as portfolio flows rather than direct investment flows. This treatment was described as in accord with the IMF guidelines mentioned above. It involved three groups of U.S. affiliates "...that had characteristics of financial intermediaries: (1) Financial affiliates located in the Netherlands Antilles, (2) financial affiliates whose U.S. parents are depository institutions, and (3) financial affiliates whose U.S. parents are securities dealers" (U.S. Department of Commerce, 1998b, pp. 119-120).

The effect of the revised treatment was substantial. In 1997, for example, the net outflow of direct investment from the United States was reduced by $\$ 11$ billion, leaving a revised total of $\$ 119$ billion after other adjustments. The inward flow was reduced by $\$ 54$ billion, leaving a revised total of $\$ 108$ billion. A similar change was made on the inward investment side, excluding intercompany debt positions with financial affiliates whose ultimate beneficial owners were depositary institutions or finance or insurance firms (Bach, 1998, p. 52). 
A major effect of the change was on the reported volatility of FDI flows. These financial intermediary flows fluctuated far more widely than the remaining FDI flows, at least in 19941997, the period for which the revisions were published. On the outward investment side, the changes in the financial intermediary flow ranged from a negative $\$ 2$ billion to a positive $\$ 11$ billion, while the revised total, excluding the financial intermediaries, varied from negative $\$ 75$ billion to negative $\$ 122$ billion, with no changes of direction. On the inward side, the financial intermediary flows, all negative, ranged from $\$-1$ billion to $\$-54$ billion, while the revised flows (inflows), excluding the intermediaries, all positive, increased in every year, from $\$ 46$ to $\$ 108$ billion (Bach, 1998, Table 3).

Another way of describing the volatility of the financial intermediary flows is by comparing the average annual changes to the average annual flows. The average annual change in the outward flow for the financial intermediaries was over $100 \%$ of the average flow for the period, while the average change in the adjusted outflow was only $16 \%$ of the average adjusted outflow. On the inward side, the average change in the intermediaries' inflow was $120 \%$ of the average inflow while the average change in the inflows excluding the intermediaries was $24 \%$ of the average adjusted inflow. Thus, the financial intermediaries' flows were 5 to 6 times as volatile as the rest of the direct investment flows.

The question of how to treat financial intermediary subsidiaries was not a new one. The United States outward investment total for many years showed a negative investment in the Netherlands Antilles that reached a peak of \$-25 billion in 1984 . That was $12 \%$ of the reported outward direct investment total, and over $40 \%$ of the reported investment in trade and services, excluding petroleum services (Lipsey, 1988, Table 8.A.1). These large investments in the Netherlands Antilles were a result of the U.S. withholding tax on interest paid by U.S. firms on 
borrowing abroad. U. S. parent firms set up affiliates in the Netherlands Antilles to borrow in European capital markets, free of the tax on interest payments, and relend the proceeds to their parents. In this way, a portfolio flow, mainly bond issues, was magically converted into a direct investment flow by passing through the affiliates. Since the direct investment flow was of parent firms borrowing from their affiliates, it became a negative element in the U.S. outward investment position.

\section{Do Investment Stocks Reflect the Economic Activity of Multinational Firms?}

The only virtually universal measure of the activities of multinational firms outside their home countries is the amount of direct investment, or the "direct investment position," of a country, as calculated from direct investment stock data or cumulated flows of direct investment. These are the FDI data derived from balance of payments statistics. They do not purport to measure the size of multinational firms or their foreign affiliates, or their activities in their host countries. They measure only the value of the parent firms' financial stakes in their foreign affiliates. However, because of their wide coverage of countries, they are often used in analyses of the impacts of MNC activities on, for example, trade, or host country, home country, or parent employment or output.

Given this use of one concept of FDI to represent another, it would be useful to know how closely the investment position data are related to, for example, the economic activity of affiliates. One reason to expect that the relation might not be close is that the investment position data are based on the immediate sources and destinations of investment. In contrast, U.S. surveys of the operations of U.S. firms abroad and foreign firms in the United States are based on the ultimate sources and final destinations of investment. An example of the difference is that, for example, of 234 affiliates in the United States with ultimate beneficial owners (UBOs) 
that were Italian in 1987, 74 reported that their immediate parent was in a country other than Italy. Of 19 affiliates with South African UBOs, 17 reported other immediate parentage and of 123 affiliates of Saudi Arabian UBOs, 105 reported other parent locations (U.S. Department of Commerce, 2001, p. M-12).

The same problem could affect the industry distribution of investment positions and affiliate activities. The investment position may report a holding company in an intermediate country as the source or destination of an investment that originated in an industrial firm or is intended for an industrial affiliate. The problem has become more serious over time because “...U.S. parent companies have been funneling an increasing share of their direct investments abroad through holding companies. In 1982, foreign affiliates classified as holding companies accounted for only 9 percent of the U.S. direct investment position abroad, but by 2000 , they accounted for 23 percent...” (Borga and Mataloni, 2001, p. 23).

Another problem with the reported stocks of FDI is that they are mostly cumulations of past direct investment flows and take no account of changes in currency values and asset values since the original investments were made. One exception to this is the FDI stock estimates for the United States, which come in three variants, historical cost, current cost, and market value. They all take account of currency value changes and, as is explained later, the current cost estimates take account of price changes on fixed assets and the market value estimates take account of equity price changes.

An examination of the relation of FDI stock to FDI activity was performed for the United States, the only country for which the comparison can be made by industry and location for a variety of activity measures (United Nations, 2000b, Annex D). It showed that in 1989, the distribution of the U.S. outward FDI stock across host countries was strongly correlated with the 
distribution of affiliate sales. The distribution of the U.S. inward FDI stock across countries of origin was similarly well correlated with the sales and employment of those countries' affiliates in the United States. However, changes in the country distribution of U.S. outward FDI were not closely related to changes in the location of sales and employment. The country distribution of changes in inward investment was weakly related to changes in the country distribution of employment $(\mathrm{r}=.37)$ and not related at all to changes in the country distribution of sales $(\mathrm{r}=.015)$. Thus it appeared that the country distributions of outward and inward investment stocks in one year were related to the country distributions of sales and employment, but changes in country distributions were poor indicators of changes in employment and sales.

Tests of the relation of the outward stock of FDI to measures of FDI activity for recent years are reported in Appendix Tables 7 through 10. If one wished to estimate the distribution of factor inputs or sales across both countries and industries from data on FDI stocks, the results would be quite inaccurate. Across 12 industry groups and 58 countries, less than $30 \%$ of the variation is explained, even for sales. $16 \%$ is explained for property plant, and equipment (PP\&E), and $10 \%$ for employment (Appendix Table 8). Thus, while the distributions of aggregate FDI stocks, and stocks within broad industries, are fairly well related to the distributions of input and sales measures across countries, they are only weakly related to the distributions across even broad industry groups. For a finer level of industry detail, 63 industries and nine countries, only about $10 \%$ of the variation in sales is explained, and the relationship is even weaker for PP\&E (4 \%) and employment (2\%).

Absolute changes in aggregate and total manufacturing U.S. outward direct investment stocks between 1982 and 1998 are quite closely related, across countries, to absolute changes in affiliate PPE and sales (Appendix Table 9), but the relations are much weaker for relative 
changes in these variables. Again, if we examine the relationships across both countries and broad industry groups, or across country groups and detailed industries, they fall apart. None of the rsqs is above .30 and most are below .20 (Appendix Table 10).

Thus, while the investment stocks tell us something about the country of location of FDI activity or changes in it, in the aggregate and within industries, they tell us very little about what kind of activity is taking place, or what they tell us is often wrong.

\section{History}

\section{A Brief History of FDI and its Importance in International Capital Flows}

FDI is sometimes thought of as originating with American firms, and some of its characteristics as we know it today developed mainly in American companies. However, Mira Wilkins has called attention to its antecedents far back in history. “...in 2500 B.C., Sumerian merchants found in their foreign commerce that they needed men stationed abroad to receive, to store, and to sell their goods...the East India Company, chartered in London in 1600, established branches overseas...In the mid-seventeenth century, English, French, and Dutch mercantile families sent relatives to America and to the West Indies to represent their firms. So too, in time, American colonists found in their own foreign trade that it was desirable to have correspondents, agents, and, on occasion, branch houses in important trading centers to warehouse and to sell American exports..." (1970, p. 1).

Wilkins describes the Virginia Company, chartered by King James I in 1606 to establish the first permanent English settlement at Jamestown, as “...the first foreign direct investment in America..." (1989, p. 6). By 1624 it was bankrupt. She identifies 1875-1914 as the period of "...the rise of truly large-scale foreign investments in the private sector" (p. 609) including “...more foreign direct investments than most subsequent commentaries have recognized" (p. 
613). Wilkins divides direct investments into two types. "One involved investments that carried the potentials of control, but had a fragile, negligible, sometimes virtually nonexistent 'home office' organization with little capacity beyond that of raising capital. These companies had no experience in operations at home to project abroad.... The second type of direct investment, akin to today's multinational enterprises, provided the extension into the United States of a company and its operating organizational talents- its own ' package' of skills, experience, technology, management, and marketing experience” (pp. 613-614).

In view of the current interest in multinationals and direct investment, it is striking that they play a minor role in descriptions of the period before 1913, the time of perhaps the largest total international investment flows in history, relative to output and fixed investment. Most writings about capital movements either did not mention direct investment at all (Iverson, 1936) or treated it as a minor form of international investment. Hobson (1914, p. 25) did describe “... an enormous rise in the importance of the international company, in railways, mining, tramways, water, gas, electricity, banking, insurance, finance, land plantations..." and even manufacturing, “...but there it is still somewhat rare.” The consensus was probably well summarized by Arthur Bloomfield's appraisal that "portfolio investment was a far more important component of long-term capital movements before 1914 than direct investment" (1968, p. 3). He noted one exception, China, among developing country recipients of investment, and one, the United States, among developed country investors. Another exception was apparently Japan as an investor, the counterpart of China as a recipient, as indicated in a number of sources cited in Wilkins (1986, pp. 3-4). Bloomfield suggested that before 1914, “... the concept of direct investment (in its present-day sense) was not clearly distinguished from other (noncontrolling) equity investments in foreign private enterprises (Bloomfield, pp. 3-4). 
Svedberg (1978) challenged the idea that direct investment flows to developing countries were negligible before 1914. He claimed that it was an illusion stemming from the typical methods of estimating investment flows and stocks. These relied heavily on public flotations of securities and therefore missed many direct investments that did not pass through such exchanges. Svedberg estimated that some 44 to $60 \%$ of the $\$ 19$ billion of accumulated investment in developing countries in 1913-14 was in the form of direct investment. Mira Wilkins, too, argued that "foreign direct investments... have often been shortchanged in the literature of U.S. economic history...” (1989, p.xi).

For more recent years, the International Monetary Fund has published comprehensive worldwide estimates of gross and net flows of direct investment since 1970, gross flows of portfolio and other investment since 1980, and net flows since 1970. Portfolio investment includes equity securities, debt securities in the form of bonds, money market instruments, and financial derivatives, such as options, all excluding any of these included in direct investment or reserve assets. The category of "Other investment" includes trade credit, loans, financial leases,

The data on gross direct investment flows indicate that direct investment has been an increasing part of total investment flows since the 1970s and early 1980s, when they were less than $15 \%$. By the first half of the 1990 s they accounted for $30 \%$ of total outflows and they stayed at that level in the second half of the decade (Table 1). The largest source of gross direct investment flows since the 1980s has been Europe, followed by the United States. Japan was the next major source until the 1990s, when it was overtaken and passed by Developing Asia (Lipsey, 1999, Appendix Table 6A.2 and Appendix Table 2 of this paper). A large part of European outflows has stayed within Europe; inflows into Europe were more than half of outflows in the 1970s and 1980s (Lipsey, 1999, Appendix Tables 6A.2 and 6A.3). That pattern 
persisted into the 1990s, with inflows two thirds or more of outflows (Appendix Tables 2 and 3). The United States, too, has been a major recipient of direct investment inflows, with the result that its former position as a major net provider of direct investment to other countries has almost disappeared. In the 1980s the United States was a net recipient of direct investment from abroad, turned back to being a net supplier in the early 1990s, and again became a net recipient in the second half of the 1990s. Europe and Japan were more consistent, both being net suppliers, while Developing Asia and Latin America were steady net recipients (Lipsey, 1999, Appendix Table 6A4 and Appendix Table 4 of this paper). Thus, a large part of the gross flows of direct investment are among the developed countries.

It is difficult to compare gross or net flows of direct investment with fixed capital expenditures for the world as a whole, but a comparison can be made for the OECD countries. Among 22 countries from 1970 through 1995, the average ratios of inward FDI flows to gross fixed capital formation were below $10 \%$ in 20 countries, and they were below $5 \%$ in most of the countries. When gross inflows in a five-year period were related to fixed capital formation in the subsequent five-year period, the coefficient was negative, although not statistically significant. It did not appear that FDI inflows were a major source of financing for capital formation in these countries. Gross outflows were negatively and significantly related to capital formation in the following period, but net flows were not related to capital formation at all (Lipsey, 2001). Thus there is some suggestion that outward direct investment competes with domestic plant and equipment expenditures for funds, as was found also for a group of U.S. companies by Stevens and Lipsey (1992), but it is surprising that neither gross nor net inward FDI flows offset that competition. 
Another way of judging the importance of FDI in the world economy is to ask how much of world production and employment are accounted for by the foreign operations that result from FDI, or "internationalized production." In the late 1950s, when a large part of the outward stock of FDI was owned by U.S. firms, internationalized production might have represented about $2 \%$ of world output. By the late 1970s or early 1980s, after the period of rapid growth in U.S.owned production abroad, the share reached $5 \%$. As U.S. firms' operations abroad were reduced in the 1980s, those of other countries, particularly Germany and Japan, increased, but the pace of internationalization for the world as a whole was slower. In the 1990s, American firms resumed the growth of their overseas activities and the worldwide pace of internationalization rose again. By the late 1990 s, about $8 \%$ of world production was internationalized (United Nations 2000b).

These shares of output may not appear as large as one might expect from the volume of discussion of "globalization." One reason for a different impression is that direct investment and the resulting production are concentrated in two visible and closely watched sectors, manufacturing and petroleum. In the case of the United States, for example, in the mid-1990s, these sectors accounted for about $18 \%$ of GDP, but for three quarters of U.S.-owned overseas production. U.S.-owned affiliate production abroad was about $17 \%$ of home production in manufacturing, $100 \%$ in petroleum, but only $2 \%$ in all the other industries combined, which accounted for over $80 \%$ of total U.S. output (Lipsey, 1998). Since the manufacturing and petroleum sectors are the source of most tradables, multinational firms account for a large proportion of international goods trade. In manufacturing, for example, exports by manufacturing affiliates of firms the United States, Japan, and Sweden, were about $10 \%$ of world manufactured exports in the mid-1990s. Since those three countries accounted for only 
about a third of the stock of outward FDI, if their affiliates' export propensities were not far from the average, the total internationalized share of manufactured exports might be somewhere around $30 \%$.

In mining, of which petroleum is a large part, the output of foreign affiliates of U.S. firms alone was almost a quarter of world output in 1977, but fell below $20 \%$ by 1990 . The decline was much larger in developing countries, from 23 to $10 \%$ (Mataloni and Goldberg, 1994, and United Nations, 1993), as several Middle Eastern countries nationalized what had formerly been U.S.-owned properties.

The share of internationalized production in world manufacturing output is much higher than the share in total output. It was about $11 \& 1 / 2 \%$ in 1977 , when the share in total output was around $5 \%$. By 1990 it was over $16 \%$ when the share in total output was less than half of that, and it has probably risen somewhat since then (Lipsey, 1998, pp. 12-13).

The share of world employment absorbed by internationalized production is far smaller than the share of production itself. It was probably not much above $1 \%$ in the late $1990 \mathrm{~s}$, as compared with $8 \%$ for production. The implication is obviously that output per worker was seven or eight times as high in internationalized production as in world production in general, the consequence of some combination of greater capital intensity and higher productivity (United Nations 2000b).

\section{The United States as a Direct Investor and Recipient of Direct Investment}

The United States has been, since its earliest days as a foreign investor, exceptionally focused on direct investment. Frank Southard, in one of the first studies of U.S. direct investment, commented about that early start. "...it was the two decades just prior to the opening of the 
present century (the $20^{\text {th }}$ ) that saw a startling development: the export of capital in significant amounts by American corporations for the establishment of European plants and sales organizations at a time when the United States was steadily importing capital" ( 1931,p. xiii). In 1897, the United States, still predominantly a net recipient of capital from abroad, rather than a supplier of capital, held more than $90 \%$ of its outward investment in the form of direct investment (Lewis, 1938, p. 605). By 1914, that share had declined to three quarters, but it was still far above the proportion in foreign investment in the United States (ibid), and in worldwide investment. World War I was the beginning of major U.S. portfolio investment abroad, much of it in the form of loans to foreign governments that exceeded private financing. By the end of the war, in 1919, direct investment had been reduced to a little over half of U.S. private investment abroad, and to less than a quarter of total investment, including intergovernmental loans (ibid, $\mathrm{p}$. 447). Both direct and portfolio investment grew rapidly during the 1920s, but that period differed from earlier ones in that portfolio investment accounted for a majority of the outward flow. By 1929, the value of U.S. private portfolio investment abroad was greater than that of direct investment for the first time (Lewis, pp. 450, 605).

The Great Depression of the 1930s reversed this movement toward the portfolio form that had taken place in the 1920s. Half of the foreign loans extended in the late 1920s went into default (Mintz, 1951, p. 6). U.S. holdings of securities of securities, even valued at par rather than market, were reduced by almost $30 \%$, or by almost $50 \%$ if defaulted bonds were valued at market prices. Short-term credits were also reduced almost by half (Lewis, 1938, p. 454). By 1940 direct investment again accounted for more than half of U.S. private investment abroad, and that remained true through 1970 (U.S. Bureau of the Census, 1975, series U26-U39).

U.S. government loans to foreign countries had expanded again during World War II and by 
1950 the stock of such loans was almost twice the total private investment stock. Thus the restored dominance of direct investment in 1950 applied only to private investment.

By the late 1970s, the stock of direct investment, measured in the traditional way at book, or historical cost values, had fallen to between 40 and $50 \%$ of total private investment abroad, where other types of assets were measured at market values, where possible (Table 2). There was some suspicion that historical cost valuation might seriously distort the valuation of direct investment, and in 1991, the BEA began to offer two alternative valuation methods (Landefeld and Lawson, 1991). One, referred to as "current-cost" valuation, attempted to apply inflation accounting to the asset side of the balance sheets of U.S.-owned affiliates abroad and foreignowned affiliates in the United States. The tangible assets of affiliates were revalued, using a perpetual inventory calculation for plant and equipment and current price indexes for other forms of tangible capital. The "market valuation" method revalues, instead, the equity part of the parent's investment in affiliates, using broad stock price indexes for foreign countries and the United States.

By the current cost valuation, the share of direct investment in U.S. private investment abroad was still close to $60 \%$ in the late 1970 s as compared with about $45 \%$ by the historical valuation (Table 2). After that, the direct investment share fell, almost continuously, to about one quarter in 1997-99. Although the share fell in almost every year, most of the decline took place in the burst of portfolio and short-term lending that took place before and during the Latin American crisis of the early 1980s. Both the current-cost and historical valuations showed a direct investment share of 20 to $25 \%$ in U.S. outward investment in the late 1990s, but the market value share, propelled by the rise in stock prices, produced a direct investment share of 35-40 \% (Table 2). Some part of the reduction in the share of direct investment in the outward stock of private 
foreign investment stemmed from large upward revisions, by about $30 \%$, in the estimates for purchases of foreign securities. The revisions stemmed mainly from two sources. One was a U.S. Treasury Benchmark Survey of U.S. Portfolio Investment Abroad at yearend 1997, which indicated a $20 \%$ discrepancy between previous estimates and the survey results in the brief period since the previous survey in 1994. The other was an adjustment for U.S. portfolio investment that took place in the course of foreign acquisitions of U.S. firms, when the purchasing firms paid U.S. stockholders with stock in the foreign acquirers (Bach, 2000, pp. 70-72).

Not only did the United States have an exceptional share of its foreign investment in direct investment, but it also accounted for a large part of the world's stock of outward direct investment. In 1960, almost half of the world's outward stock of direct investment was owned by investors based in the United States. No other country came close to that share; the next ranking holder was the UK, at $18 \%$, followed by the Netherlands at $10 \%$ and France at $6 \%$ (United Nations, 1988, Table 1.2). By 1999, the U.S. share had fallen to less than a quarter. The UK, The Netherlands, and France remained important, the first two with reduced shares. Germany and Japan, with only $2 \%$ of the total between them in 1960 , accounted for $15 \%$ in 1999 . Even developing countries, which had been the homes for only $3 \%$ of the outward stock as late as 1980, owned $10 \%$ of it in 1999 (United Nations, 2000a). Thus, the ability of firms to operate in foreign countries had become much more widely diffused among home countries over those 40 years.

Another indicator of that diffusion was the change in the direct investment balance of the United States. In the late 1970s, U.S. direct investment abroad was about four times the value of foreign direct investment in the United States, both measured at current values. By 1997-99, foreign direct investment in the United States had reached over three quarters of the level of U.S. 
direct investment abroad. The net U.S. direct investment position, which had been a little over \$200 billion in 1977-79, was only about \$240 billion in 1997-99, when gross outward investment was five times as large.

\section{Data On Foreign Direct Investment}

There are two general types of data on foreign direct investment. One is the financial data from balance-of -payments accounting. These record inward and outward flows of direct investment and the resulting stocks. The stocks are the value of stocks of direct investment outside each home country owned by residents of that country and the value of stocks in each country that are owned by residents of other countries.

The second type of data is on the operations of FDI affiliates in their host countries and the operations of their parents in their home countries. Operations could include their sales, production, employment, wages, assets, expenditures for plant and equipment, and R\&D expenditures. None of these characteristics are revealed by the financial data from the balanceof-payments. They are obtained from surveys of parent companies, in their home countries, or , in their host countries, from surveys of affiliates, often by identifying foreign-owned establishments in economic censuses.

\section{Data on FDI Flows and Stocks}

The only data on direct investment that cover virtually all countries are the balance of payments, or financial data. These are reported to the International Monetary Fund and are published, for example, in IMF (2000a). The reports are separated into outward ("Abroad") and inward (In Reporting Economy") flows, divided between reinvested earnings and other direct investment flows. Notes are provided explaining the sources of data for each country. In the past, many 
countries did not record reinvested earnings, but coverage has improved in recent years. The worldwide discrepancy between outward and inward direct investment flows, which should be zero if all flows were recorded fully and consistently by both sides, has been no higher than $8 \%$ in any year from 1993 to 1999 , as contrasted with 40 or $50 \%$ for portfolio investment.

The Balance of Payments Yearbooks also call for the reporting of inward and outward stocks of direct investment, as part of their tabulations of the international investment position of each country. Most developed countries report their inward and outward stocks of FDI, but many developing countries do not. The IMF data, in summary form, are also available in International Financial Statistics, for example, IMF (2000b).

The quality of international data on FDI flows for measuring what is called for in balance of payments accounting was reviewed in IMF (1986) as part of the search for an explanation and cure for the enormous world balance of payments discrepancies. The world current account discrepancy did fall for a while, but it returned to well over negative \$100 billion in 1999 (IMF 2000a). The discrepancy for direct investment, which had been fairly small during most of the 1990s, jumped to $\$ 64$ billion in 1999 , about $7 \& 1 / 2 \%$ of the reported outflow.

A deficiency of all the IMF compilations is that political considerations apparently dictate the omission of data for two important entities, Taiwan, and until 1998, Hong Kong. However, Taiwan does publish its data in the IMF format.

A source of inward and outward FDI flow and stock data that covers almost all countries is the UNCTAD World Investment Report (WIR), for example, United Nations (2000a). These reports began with United Nations (1973), (1978), (1983), and (1988), and have been published annually since 1991. They provide annual data from 1990 to 1999 and at five-year intervals before that. There are also extensive notes on sources and listings of items omitted in various 
countries' reports. Annex B includes listings for each country covered indicating what items are omitted, sources of data, and major revisions. There are also tables of ratios of FDI flows to Gross Capital Formation and of FDI stocks to GDP. In contrast to the IMF reports, the WIR has consistently included information on FDI in and by Taiwan and Hong Kong.

A source of financial data on FDI that covers quite a few countries is the OECD International Direct Investment Statistics Yearbook, covering 28 countries in its latest edition (OECD 2000), although not with complete data for all of them. It includes data on inflows and outflows and on inward and outward stocks, or the "direct investment position." A major advantage over the compilations of the IMF and UNCTAD is that there are data for most countries by broad industrial sectors and also by partner country, in a uniform format.

Data on direct investment flows and the international direct investment position of the United States are published regularly in articles in the Survey of Current Business and have been summarized in a series of publications by the Bureau of Economic Analysis. The period beginning in 1950 was covered, with substantial country detail, and a little industry information, especially starting in 1966, in U.S. Department of Commerce (1982). Recent editions have included greater industry detail.

The traditional way of measuring inward and outward investment stocks at historical valuations came under increasing criticism in the 1980s. It did not take account of changes in prices and did not match the treatment of fixed capital in the U.S. National Income and Product Accounts. As a result, the BEA, in 1991, began to publish its U.S. investment position data in two alternative valuations, as mentioned earlier. One was a "current-cost" valuation, in which inflation accounting was applied to the assets of U.S. affiliates abroad and foreign affiliates in the United States. Affiliate tangible assets were revalued using a perpetual inventory calculation for 
plant and equipment and current price indexes for other types of tangible capital. The other method, described as "market valuation," revalues, instead, the liability side, in particular, the equity portion of the parent investment in affiliates. It uses broad equity price indexes for foreign countries to value the equity portion of U.S. assets abroad and equity price indexes for the United States to value the equity portion of foreign assets in the United States.

As is pointed out in the article announcing the new measures (Landefeld and Lawson, 1991), there are limitations to these measures, although not as great as those of the historical valuations. The new measures are the only ones now reported in the articles on the international investment position of the United States. The inward investment measures at current cost are probably the most accurate of the four, two inward and two outward. The BEA produces price measures for U.S. plant and equipment expenditures, and the only possibly major problem is that the composition of plant and equipment expenditures by foreign affiliates in the United States is not known in detail and could differ from that of other firms in the United States. The outward investment measure at current cost must make do with available foreign price indexes for capital goods. These do not exist for all the host countries, and even where they do, are not collected and calculated in comparable ways. The market value measures rely on the assumption that the market values of what are mainly privately-owned companies follow those of broad stock price indexes. The composition of these indexes may differ substantially with respect to industry, country, in the case of outward investment, and in other respects from the composition of the equities that are part of direct investment. 


\section{Data on FDI Operations}

The balance of payments data suffer from two incurable problems. One is that, as described earlier, they trace only the immediate sources and destinations of investment, rather than the ultimate ones. A more serious one is that they contain no information on the economic activity of FDI affiliates and their parents. Thus they tell nothing about the characteristics of the parents, such as their industry, their size, employment, sales, assets, or technological activities. It is therefore difficult to use them to study the reasons for companies to invest in production abroad or the choices they make in such investing. The financial data also tell nothing about the economic activities of the affiliates. It is therefore difficult to use them to analyze the impacts of the affiliates' operations on their host countries or on the parents and their home countries. The only possible sources of information on the operations of parents are surveys carried out in their home countries. Information on the operations of affiliates can be collected from surveys of parent firms in their home countries or my surveys of affiliates in the host countries, done either specifically to examine foreign-owned operations or as part of economic censuses by tagging foreign-owned firms or establishments.

The most comprehensive data, by far, on FDI operations are those for the United States. Annual data on the operations of both U.S. nonbank affiliates abroad and foreign nonbank affiliates in the United States are published in articles in the Survey of Current Business. More complete data, and particularly more U.S. parent data, are published in reports published every year by the Bureau of Economic Analysis (BEA). The most complete sets of information, include banking, appear in the BEA's benchmark surveys, which are usually conducted every 
five years. The latest inward survey is U.S. Department of Commerce (2001), covering 1997, and the latest outward survey is U.S. Department of Commerce (1998a).

Among the items included are balance sheets, income accounts, employment, exports, to affiliates and to others, imports, and R\&D expenditures and employment. The benchmark surveys include more topics and more country and industry detail than the annual surveys.

The United States also provides measures of the production, or gross product, of U.S. parents and affiliates and of foreign affiliates in the United States. That measure of FDI activity is preferable to sales or employment, partly because of its comparability with national accounts concepts, such as GDP. For U.S. affiliates abroad it is calculated for only majority-owned ones (MOFAs), because the survey form for other affiliates, which account for between 12 and $17 \%$ of total activity, depending on the measure used, lacks the required information (U.S. Department of Commerce, 2000c, Tables II.A-1 and III.A-1).

The estimates are built up by summation of factor costs and indirect taxes rather than by subtraction of intermediate inputs from gross output. They match the gross product measures in the National Income and Product Accounts (NIPAs) fairly well in concept. One difference is that depreciation is reported only at book value instead of the NIPA's current value, using economic service lives and replacement cost valuation (Mataloni and Goldberg, 1994, p. 42). The effect is on the distinction between depreciation and profits within affiliates, rather than on total gross profit.

On the inward side, the BEA and the Census Bureau have matched reporting firm identifications to identify foreign-owned U.S. establishments They can thus provide U.S. economic census establishment data divided between domestically-owned and foreign-owned establishments. These have been published for 1987 and 1992 for most U.S. industries, in U.S. 
Department of Commerce (1992) and (1997), and the linked data for 1997 are expected to be published in 2002. For years between 1987 and 1992, only manufacturing is covered, in a series of annual publications. The industry and geographical detail are extensive, but only a few items such as numbers of establishments, employment, and wages, are reported. An important distinction between these data and the BEA survey data is that the matched data are on an establishment basis, rather than an enterprise basis. A large enterprise often combines establishments belonging to several industries, possibly including both manufacturing and wholesale trade or manufacturing and mining, in the case of petroleum, the establishment data provide a more accurate account of the industry distribution of foreign-owned employment, sales, and other variables.

A broader assessment of the quality of U.S. data on FDI, dealing with concepts as well as arithmetic accuracy, is given in Stekler and Stevens (1991).

The OECD has begun to publish some data for inward investment operations in member countries, in, for example, OECD (1999). Response is not complete, but the publication attempts to cover numbers of foreign-owned enterprises and their production, turnover, value added, wages and salaries, $\mathrm{R} \& \mathrm{D}$ expenditures and employment, and trade.

Operations by Swedish firms abroad beginning in 1965 can be studied from surveys conducted at approximately five-year intervals by the Industriens Utredningsinstitut of Stockholm (now known as The Research Institute of Industrial Economics). Publications reporting on these surveys are listed in the references to Swedenborg (2001). The surveys included questions on employment, wages, fixed capital, trade, R\&D expenditures, and other topics, mostly relating to foreign affiliates, but with some information about parents and about the relations between parents and affiliates.. 
The Swedish Central Bureau of Statistics (Statistics Sweden) has been publishing data starting in 1990 on employment at home and abroad in Swedish-owned enterprise groups having subsidiaries abroad. The data are reported by detailed industry and by country, but not crossclassified, except to distinguish manufacturing from service industries (Sweden, Statistics Sweden, 2000a). A survey of R\&D expenditures and R\&D personnel input in Sweden and abroad in the twenty largest Swedish manufacturing groups and in foreign-owned enterprises in Sweden was conducted for 1997 (Sweden, Statistics Sweden, 2001).

A limited report on operations of foreign firms in Sweden was published annually by the Central Bureau of Statistics, starting with 1987. A much more extensive survey and analysis for 1970 appears in Samuelsson (1977). Beginning in 1994, the scope of reporting was expanded, although the survey remained voluntary. As in the outward survey, the main question is on employment, classified by industry and country of origin (Sweden, Statistics Sweden, 2000b). For 1997, a supplementary report included data on profits, liquidity, exports and export intensity, and value added (Sweden, Statistics Sweden, 2000c).

Information on the operations of both German firms abroad and foreign firms in Germany is has been published in a series of reports by the Deutsche Bundesbank, at two-year intervals, such as in Deutsche Bundesbank (1999). The country and industry detail are extensive, but the list of variables is short, limited to numbers of firms, employment, annual turnover, and assets, with some breakdown by type of asset.

For Japan, the Ministry of International Trade and Industry (MITI, now METI), has published a series of annual and benchmark surveys of outward FDI since the 1970s. They contain a great deal of information on parent and affiliate operations, but suffer from low response, fluctuating over time and varying, within a survey, from question to question. The 
coverage and other quality aspects of these surveys have been discussed in Ramstetter (1996), and some of the individual MITI publications are listed there.

Recently, there have been efforts, supported by Japanese official agencies, to improve the quality of the MITI data. A paper by Fukao, Yuan, and Sakishita (1999) estimated missing data from survey forms to produce better approximations to total employment and sales by Japanese affiliates and their distribution over host countries and industries.

The United Kingdom does not conduct regular surveys of its firms' outward FDI activities. A major one- time survey was conducted for the Reddaway (1967) and (1968) reports, but it was not repeated. Inward FDI activities can be followed by using economic census data, where foreign ownership is tagged.

France does not publish any readily available public data on the outward FDI activities of its firms. The French government has issued, since the 1970s, a series of reports on numbers of foreign-owned firms and their employment, wages, capital, and exports and, for each measure, the share in the French economy. The data are disaggregated by industry, country of origin, and location within France. The latest report, covering January 1, 1998, was summarized in France, SESSI (2000).

Canada is one of the world's major recipients of FDI and has a long history of collecting data on it, mainly on sales, exports, imports, and financial aspects. An early survey for 1964 and 1965 was published in Canada (1967). Employment, hours of work, and wages were added in some later surveys, such as Canada (1979), but the main source of data remains the reports under the Corporations and Labour Unions Returns Act, published by Statistics Canada in recent years. For the period of operation of the Foreign Investment Review Act, from 1974 to 1985, detailed 
data were published for individual firm applications to invest in Canada. These appeared in the annual reports of the review agency, the last of which was Canada (1985).

A collection of the available data on production at home and abroad by home country multinational firms and of production in many host countries by foreign-owned firms was assembled in Lipsey, Ramstetter, and Blomström (1998). Detailed source notes appeared in Lipsey, Blomström, and Ramstetter, (1995). Among the host countries covered in Asia were China, India, Indonesia, Korea, Malaysia, Singapore, Taiwan, and Thailand, and in Latin America, Brazil, Mexico, and Uruguay. Developed host countries covered were Australia, Canada, Japan, Norway, the United Kingdom, and the United States. A broader collection of indicators of multinational activity other than production is provided in United Nations (2001).

There have been several extensive surveys of the literature and research on multinational firms and FDI, fairly comprehensive at the time they were written. Two of the most extensive in coverage are Caves (1996) and Dunning (1992). 


\section{$\underline{\text { References }}$}

Bach, Christopher L., "U.S. International Transactions, Revised Estimates for 1986-97," Survey of Current Business 78, No. 7, (1998):47-57.

, "U.S. International Transactions: Revised Estimates for 1982-99," Survey

of Current Business 80, No. 7, (2000):70-77.

Bargas, Sylvia E., "Direct Investment Positions for 1999: Country and Industry Detail," Survey of Current Business 80, No. 7, (2000):58-69.

Borga, Maria, and Raymond J. Mataloni, Jr., "Direct Investment Position for 2000: Country and Industry Detail," Survey of Current Business 81, No. 7, (2001):16-29.

Bloomfield, Arthur I., Patterns of Fluctuations in International Investment Before 1914, Princeton Studies in International Finance No. 21, (1968) Princeton, NJ, Princeton University, International Finance Section.

Canada, Foreign-Owned Subsidiaries in Canada, Dominion Bureau of Statistics and Department of Trade and Commerce, May, 1967. May, 1978.

, Compendium of Statistics on Foreign Investment, Foreign Investment Review Agency, , Domestic and Foreign Control of Manufacturing, Mining, and Logging Establishments in Canada, 1974, Statistics Canada, January, 1979.

, Foreign Investment Review Act, Final Annual Report, 1984-85, Investment Canada, September, 1985.

Caves, Richard E., Multinational Enterprise and Economic Analysis, $2^{\text {nd }}$ Edition, Cambridge Surveys of Economic Literature, Cambridge, Cambridge University Press, 1996.

Deutsche Bundesbank, Kapitalverflechtung mit dem Ausland,_Statistische Sonderveröffentlichung 10, Frankfurt am Main, June, 1999.

Dunning, John H., Studies in International Investment, London, George Allen \& Unwin, Ltd., 1970.

, Multinational Enterprises and the Global Economy, Wokingham, England, Addison-Wesley Publishing Co., 1992.

Edelstein, Michael, Overseas Investment in the Age of High Imperialism: The United Kingdom, 1850-1914, New York, Columbia University Press, 1982. 
France, SESSI (Service des Statistiques Industrielle), "Les entreprises étrangère dans l'industrie francaise: Une forte implantation", Les 4 Pages des statistique industrielle, No. 132, juin (2000).

Fukao, Kyoji, Tangjun Yuan, and Makoto Sakishita, "Estimating Total Overseas Business Activities of Japanese Companies from Extrapolations of Panel Data Underlying the Basic and Annual Surveys," in Japan, Institute for International Trade and Investment, Ed. (1999), (in Japanese).

Hobson, C.K., The Export of Capital, London, Constable, 1914.

Howenstine, Ned G., "Gross Product of Foreign Affiliates of U.S. Companies," Survey of Current Business 57, No.2, February, 1977.

, and William J. Zeile (1994), "Characteristics of Foreign-Owned U.S. Manufacturing Establishments,” Survey of Current Business 74, No. 1, January, (1994):34-59.

IMF (International Monetary Fund, "Final Report of the Working Party on the Statistical Discrepancy in World Current Account Balances," Washington, DC, December, 1986.

International Monetary Fund, 1993. , Balance of Payments Manual, $5^{\text {th }}$ Edition, Washington, DC, International Monetary Fund, 1995. , Balance of Payments Compilation Guide, Washington, DC, International Monetary Fund, 2000a.

, Balance of Payments Statistics Yearbook, Washington, DC, , International Financial Statistics Yearbook, Washington, DC, International Monetary Fund, 2000b.

Inter-Secretariat Working Group on National Accounts, System of National Accounts: 1993, Brussels/Luxembourg, New York, Paris, Washington, DC, Eurostat, IMF, OECD, United Nations, and World Bank, 1993.

Iversen, Carl, Aspect of the Theory of International Capital Movements, Copenhagen, Levin and Munksgaard; London, Humphrey Milford and Oxford University Press, 1936.

Japan, Institute for International Trade and Investment, Ed., Analytical Research Based on Data from the Survey of Overseas Business Activities, Survey, Survey Research on Harmonizing Globalization based on the 1997 Survey of Overseas Business Activities, Tokyo, Institute for International Trade and Investment, 1999.

Kindleberger, Charles P., American Business Abroad: Six Lectures on Direct Investment, New Haven and London, Yale University Press, 1969. 
Landefeld, J. Steven, and Ann M. Lawson, "Valuation of the U.S. Net International Investment Position," Survey of Current Business 71, No. 5, May, 1991.

Lewis, Cleona, America's Stake in International Investments, Washington, DC, Brookings Institution, 1938.

Lipsey, Robert E., "Changing Patterns of International Investment in and by the United States," in Martin Feldstein (ed.), The United States in the World Economy, Chicago, University of Chicago Press, 1988, pp. 475-545.

, "Foreign-Owned Firms and U.S. Wages," Cambridge, MA, NBER Working Paper No. 4927, November 1994.

, "Outward Direct Investment and the U.S. Economy," in Martin Feldstein, James R. Hines, Jr., and R. Glenn Hubbard, (eds.), The Effects of Taxation on Multinational Corporations, Chicago, University of Chicago Press, 1995, pp.7-41.

,"Internationalized Production in Developed and Developing Countries and in Industry Sectors,” NBER Working Paper No. 6405, February, 1998.

, "The Role of FDI in International Capital Flows," in Martin Feldstein, (ed.), International Capital Flows, Chicago, University of Chicago Press, 1999, pp.307-362.

,'Interpreting Developed Countries' Foreign Direct Investment," in Deutsche Bundesbank, (ed.), Investing Today for the World of Tomorrow, Berlin, Springer-Verlag, 2001, pp. 285-325.

Lipsey, Robert E., Magnus Blomström, and Eric D. Ramstetter, "Internationalized Production in World Output," NBER Working Paper No. 5385, Cambridge, MA, National Bureau of Economic Research, December (1995).

, and , "Internationalized Production in

World Output," in Robert E. Baldwin, Robert E. Lipsey, and J. David Richardson, (eds.), Geography and Ownership as Bases for Economic Accounting, NBER Studies in Income and Wealth, Vol. 59, Chicago, University of Chicago Press, 1998, pp.83-138.

, Eric D. Ramstetter, and Magnus Blomström, "Outward FDI and Parent

Exports and Employment: Japan, the United States, and Sweden," Global Economic Quarterly 1, No. 4, 2000.

Lowe, Jeffrey H. (1990), "Gross Product of U.S. Affiliates of Foreign Companies, 1977-87," Survey of Current Business 70, No. 6, June, (1990): 45-53.

Mataloni, Raymond J., Jr., "Real Gross Product of U.S. Companies' Majority-Owned Foreign Affiliates in Manufacturing," Survey of Current Business 77, No. 4, April, (1997):8-17. 
(2000), “U.S. Multinational Companies: Operations in 1998," Survey

of Current Business 80, No. 7, (2000): 26-45.

Mataloni, Raymond J, Jr., and Lee Goldberg, "Gross Product of U.S. Multinational Corporations, 1977-91,” Survey of Current Business 74, No. 2, February, (1994):42-63.

Mintz, Ilse, Deterioration in the Quality of Foreign Bonds Issued in the United States, 19201930, New York, National Bureau of Economic Research, 1951.

OECD (Organisation for Economic Cooperation and Development), OECD Benchmark Definition of Foreign Direct Investment, 3d Edition, Paris, OECD, 1996. , Activities of Foreign Affiliates in OECD Countries, Paris, OECD, 1998. , Measuring Globalisation: The Role of Multinationals in OECD Economies, 1999 Edition, Paris, OECD, 1999. , International Direct Investment Statistics Yearbook, 1999, Paris, OECD, 2000.

Ramstetter, Eric D., "Estimating Economic Activity by Japanese Transnational Corporations: How to make sense of the Data?" Transnational Corporations 5, No.2, August (1996):107-143.

Reddaway, W.B., in collaboration with J.O.N. Perkins, S.J. Potter, and C. T. Taylor, Effects of U.K. Direct Investment Overseas: An Interim Report, Occasional Paper 12, Department of Applied Economics, Cambridge University, 1967. , in collaboration with S.J. Potter and C. T. Taylor, Effects of U.K. Direct Investment Overseas: Final Report, Occasional Paper 15, Department of Applied Economics, Cambridge University, 1968.

Republic of China, Statistical Yearbook of the Republic of China, 2000, Taiwan, Directorate General of Budget, Accounting, and Statistics, Executive Yuan, Republic of China, 2000.

Samuelsson, Hans-Fredrik, Utländska Direkta Investeringar I Sverige, Stockholm, Industriens Utredningsinstitut, 1977.

Scholl, Russell B., "The International Investment Position of the United States at Yearend 1999," Survey of Current Business 80, No. 7, July, (2000):46-56.

Southard, Frank A., Jr., American Industry in Europe, Boston and New York, Houghton Mifflin Co., 1931.

Stekler, Lois E. and Guy V. G. Stevens, "The Adequacy of U.S. Direct Investment Data," in Peter Hooper and J. David Richardson, Editors, International Economic Transactions: Issues in Measurement and Empirical Research, Studies in Income and Wealth, Vol. 55, Chicago, University of Chicago Press, 1991. 
Stevens, Guy V.G., and Robert E. Lipsey, "Interactions Between Domestic and Foreign Investment," Journal of International Money and Finance 11, No. 1, March, (1992):40-62.

Svedberg, Peter, "The Portfolio-Direct Investment Composition of Private Foreign Investment in 1914, Revisited,” Economic Journal 88, No. 352, December, (1978):763-777.

Sweden, Statistics Sweden, "Swedish owned enterprise groups having subsidiaries abroad 1997," Swedish National Board for Industrial and Technical Development (NUTEK) and Statistics Sweden, Stockholm and Örebro, 2000a.

, International Business: Foreign owned enterprises 1999, Swedish

National Board for Industrial and Technical Development and Statistics Sweden, Stockholm and Örebro, 2000b.

, Utlandsägda företag, Ekonomiska uppgifter 1997, NUTEK and Statistics Sweden, Stockholm and Örebro, 2000c. , Research and Development in international enterprises 1997, Swedish Institute for Growth Policy Studies (ITPS) and Statistics Sweden, Östersund and Stockholm, May, 2001.

Swedenborg, Birgitta, Den Svenska Industrins I Utlandet, Stockholm, Industriens Utredningsinstitut, 1973.

, The Multinational Operations of Swedish Firms: An Analysis of Determinants and Effects, Stockholm, The Industrial Institute for Economic and Social Research, 1979.

, Svensk Industri I Utlandet: En Analys av Drivkrafter och Effekter, Stockholm, Industriens Utredningsinstitut, 1982.

, "Determinants and Effects of Multinational Growth: The Swedish Case Revisited," in Magnus Blomström and Linda Goldberg, Editors, Topics in Empirical International Economics, Chicago, University of Chicago Press, 2001. , Göran Johansson-Grahn, and Mats Kinwall, Den Svenska Industrins Utlandsinvesteringar, 1960-1986, Stockholm, Industriens Utredningsinstitut, 1988.

United Nations, Multinational Corporations in the World Economy, New York, United Nations, 1973. , Transnational Corporations in World Development: A Re-Examination, Commission on Transnational Corporations, New York, United Nations, 1978. 
, Transnational Corporations in World Development: Third Survey, United Nations Centre on Transnational Corporations, New York, United Nations, 1983.

, Transnational Corporations in World Development: Trends and Prospects, Centre on Transnational Corporations, New York, United Nations, 1988.

, MSPA Handbook of World Development Statistics, Long-Term SocioEconomic Perspectives Branch, Macroeconomics and Social Policy Analysis Division, Department of Economic and Social Information and Policy Analysis, New York, United Nations, 1993.

, World Investment Report, 1998: Trends and Determinants, New York and Geneva, United Nations Conference on Trade and Development, 1998.

, World Investment Report, 1999: Foreign Direct Investment and the Challenge of Development, New York and Geneva, United Nations Conference on Trade and Development, 1999.

, World Investment Report, 2000; Cross-Border Mergers and Acquisitions and Development, New York and Geneva, United Nations Conference on Trade and Development, 2000a.

, Measures of the Transnationalization of Economic Activity, New York and Geneva, United Nations Conference on Trade and Development, $2000 \mathrm{~b}$.

U.S. Bureau of the Census, Historical Statistics of the United States, Colonial Times to 1970, Washington, DC, Government Printing Office, 1975.

U.S. Congress, House of Representatives, The Operations of Federal Agencies in Monitoring, Reporting On, and Analyzing Foreign Investments in the United States, Hearings before a Subcommittee of the Committee on Government Operations, $95^{\text {th }}$ Congress, $2^{\text {nd }}$ Session, September 19, 20, and 21, 1978, Washington, D.C., U. S. Government Printing Office, 1978.

U.S. Department of Commerce, American Direct Investments in Foreign Countries, Trade Information Bulletin No. 731, Washington, DC, GPO, 1930.

, American Direct Investments in Foreign Countries - 1936, Bureau of Foreign and Domestic Commerce, Economic Series- No.1, Washington, DC, GPO, 1938.

, Direct Private Foreign Investments of the United States: Census of 1950, A Supplement to the Survey of Current Business, Office of Business Economics, Washington, D.C. GPO, 1953.

, U.S. Direct Investment Abroad, 1966, Final Data, Bureau of Economic Analysis, Washington, D.C., U.S. Department of Commerce, 1975. 
, U.S. Direct Investment Abroad, 1977, Bureau of Economic Analysis, Washington, D.C., U.S. Department of Commerce, April, 1981.

, Selected Data on U.S. Direct Investment Abroad, 1950-1976, Washington, D.C., Bureau of Economic Analysis, February, 1982.

, U.S. Direct Investment Abroad, 1982 Benchmark Survey Data, Bureau of Economic Analysis, Washington, D.C., U.S. Department of Commerce, December, 1985.

, U.S. Direct Investment Abroad: Balance of Payments and Direct Investment Position Estimates, 1977-81, Bureau of Economic Analysis, November, 1986.

, Foreign Direct Investment in the United States: Establishment Data for 1987, Bureau of Economic Analysis and Bureau of the Census, June, 1992.

, Foreign Direct Investment in the United States: Establishment Data for 1997, Bureau of Economic Analysis and Bureau of the Census, May, 1997.

, U.S. Direct Investment Abroad: Balance of Payments and Direct Investment Position Estimates, 1982-88, Bureau of Economic Analysis, September, 1995.

, U.S. Direct Investment Abroad: 1994 Benchmark Survey, Final Results, Bureau of Economic Analysis, May, 1998a.

, "U.S. Direct Investment Abroad: Detail for Historical Cost Position and Related Capital and Income Flows, 1997," Survey of Current Business 78, No. 10, October, (1998b):117-156.

, "Foreign Direct Investment in the United States: Detail for Historical Cost Position and Related Capital and Income Flows, 1999," Survey of Current Business 80, No. 9, September (2000a):31-60.

, "U.S. Direct Investment Abroad: Detail for Historical Cost Position and Related Capital and Income Flows, 1999," Survey of Current Business 80, No. 9, September, (2000b):61-90.

, U.S. Direct Investment Abroad: Operations of U.S.

Parent Companies and Their Foreign Affiliates, 1998 Preliminary, Washington, D.C., Bureau of Economic Analysis, 2000c.

, U.S. Direct Investment Abroad: Balance of Payments \& Direct Investment Position Estimates, 1982-1999, Washington, D.C., Bureau of Economic Analysis, 2000d. 
, Foreign Direct Investment in the United States: Final

Results from the 1997 Benchmark Survey, Washington, D.C., Bureau of Economic Analysis, 2001.

Vaupel, James W., and Joan P. Curhan, The Making of Multinational Enterprise, Boston, Division of Research, Graduate School of Business Administration, Harvard University, 1969.

Wilkins, Mira, The Emergence of Multinational Enterprise: American Business Abroad from the Colonial Era to 1914, Cambridge, MA, Harvard University Press, 1970.

, "Modern European Economic History and the Multinationals," Journal of European Economic History 6, No. 3 (winter) (1977):575-95.

, “Japanese Multinational Enterprise Before 1914,” Business History Review, No. 60 (summer) (1986).

, The History of Foreign Investment in the United States to 1914, Harvard Studies in Business History, No. 41, Cambridge, MA and London, Harvard University Press, 1989. 


\section{Tables}

\section{Table 1. Share of Direct Investment in Total World Capital Outflow, 1970-1999 (Percentage)}

\section{Excluding Hong Kong \&Taiwan}

1970-74

1975-79

1980-84

11.6

1985-89

20.7

1990-94

25.4

\section{Excluding Hong Kong but including Taiwan}

$1990-94^{\mathrm{a}}$

29.7

1995-99

\section{Including Hong Kong \& Taiwan ${ }^{b}$}

1998

${ }^{a}$ Revised data.

$\mathrm{b}$ Total world capital flow does not include portfolio investment and other investment from Hong Kong.

Source: Lipsey (1999) and Appendix Table 1. 
Table 2. Share of Direct Investment in U.S. Inward and Outward Private Investment and Inward FDI Stock Relative to Outward, 1976-1999

(Percentage)

\begin{tabular}{|c|c|c|c|c|c|c|c|c|c|}
\hline \multirow{3}{*}{ Year } & \multicolumn{6}{|c|}{ Share of Direct Investment } & \multirow{2}{*}{\multicolumn{3}{|c|}{$\begin{array}{c}\text { Inward as Percentage of } \\
\text { Outward FDI Stock }\end{array}$}} \\
\hline & \multicolumn{3}{|c|}{ Outward } & \multicolumn{3}{|c|}{ Inward } & & & \\
\hline & Market & Current & Book & Market & Current & Book & Market & Current & Book \\
\hline 1976 & . & 60.4 & 48.4 & . & 25.3 & 18.0 & . & 21.4 & 22.5 \\
\hline 1977 & . & 60.0 & 47.1 & . & 27.7 & 19.3 & . & 22.5 & 23.7 \\
\hline 1978 & . & 57.2 & 43.2 & . & 28.5 & 19.7 & . & 24.2 & 26.1 \\
\hline 1979 & . & 57.5 & 43.1 & . & 28.6 & 19.7 & . & 26.3 & 29.0 \\
\hline 1980 & . & 56.0 & 41.4 & . & 32.3 & 23.8 & . & 32.8 & 38.6 \\
\hline 1981 & . & 50.6 & 36.4 & . & 34.2 & 25.5 & . & 40.4 & 47.6 \\
\hline 1982 & 30.6 & 42.1 & 28.8 & 24.3 & 31.3 & 23.5 & 57.5 & 49.4 & 60.0 \\
\hline 1983 & 29.7 & 35.3 & 24.6 & 22.6 & 27.0 & 20.7 & 55.9 & 54.5 & 64.6 \\
\hline 1984 & 28.9 & 34.4 & 24.7 & 21.7 & 26.5 & 21.0 & 63.7 & 64.2 & 75.5 \\
\hline 1985 & 35.3 & 34.4 & 25.2 & 21.9 & 24.0 & 19.1 & 56.9 & 66.6 & 77.4 \\
\hline 1986 & 38.9 & 32.7 & 24.5 & 21.8 & 22.5 & 18.4 & 51.5 & 70.3 & 81.5 \\
\hline 1987 & 39.2 & 34.3 & 26.3 & 22.2 & 23.2 & 19.2 & 53.6 & 70.0 & 80.7 \\
\hline 1988 & 39.0 & 32.2 & 24.3 & 23.4 & 23.8 & 19.7 & 56.5 & 78.2 & 90.7 \\
\hline 1989 & 39.7 & 30.5 & 23.2 & 26.0 & 23.5 & 19.5 & 64.2 & 84.6 & 96.6 \\
\hline 1990 & 36.0 & 32.1 & 24.8 & 25.9 & 24.6 & 20.3 & 73.7 & 81.9 & 91.7 \\
\hline 1991 & 37.1 & 31.4 & 25.0 & 28.7 & 24.3 & 20.1 & 80.9 & 82.9 & 89.6 \\
\hline 1992 & 35.7 & 31.6 & 25.9 & 28.0 & 23.2 & 19.2 & 86.8 & 81.4 & 84.3 \\
\hline 1993 & 36.6 & 28.9 & 24.1 & 28.2 & 23.3 & 19.3 & 74.8 & 82.0 & 82.8 \\
\hline 1994 & 35.2 & 28.6 & 23.8 & 26.0 & 22.3 & 18.2 & 71.0 & 78.6 & 78.4 \\
\hline 1995 & 36.2 & 27.8 & 23.3 & 27.8 & 20.6 & 17.0 & 76.9 & 76.8 & 76.6 \\
\hline 1996 & 35.5 & 26.2 & 22.3 & 28.6 & 19.5 & 16.3 & 80.5 & 75.3 & 75.2 \\
\hline 1997 & 35.2 & 24.4 & 21.0 & 29.8 & 17.6 & 15.1 & 92.2 & 78.0 & 79.2 \\
\hline 1998 & 37.4 & 24.9 & 21.8 & 33.1 & 17.3 & 15.2 & 100.8 & 76.9 & 78.3 \\
\hline 1999 & 37.6 & 23.5 & 20.7 & 36.0 & 18.4 & 16.5 & 107.1 & 84.5 & 87.1 \\
\hline
\end{tabular}

Source: Appendix Tables 1 and 2. 


\section{Appendix Tables}

Appendix Table 1. World Investment Outflows, 1990-1999

(Millions of U.S. Dollars)

\begin{tabular}{crrrr}
\hline Period & $\begin{array}{c}\text { Direct } \\
\text { Investment }^{\mathrm{a}}\end{array}$ & $\begin{array}{c}\text { Portfolio } \\
\text { Investment }^{\mathrm{b}}\end{array}$ & $\begin{array}{c}\text { Other } \\
\text { Investment }^{\mathrm{b}}\end{array}$ & Total $^{\mathrm{c}}$ \\
\hline 1990 & 243,012 & 187,348 & 205,411 & 635,771 \\
1991 & 198,259 & 333,194 & 164,231 & 695,684 \\
1992 & 211,378 & 353,007 & 175,953 & 740,338 \\
1993 & 245,564 & 535,832 & 177,941 & 959,337 \\
1994 & 286,163 & 337,297 & 202,183 & 825,643 \\
$1990-1994$ & 236,875 & 349,336 & 185,144 & 771,355 \\
1995 & 361,886 & 409,836 & 244,538 & $1,016,260$ \\
1996 & 396,785 & 651,301 & 267,472 & $1,315,558$ \\
1997 & 469,610 & 740,049 & 317,707 & $1,527,366$ \\
1998 & 680,768 & $1,016,928$ & 565,727 & $2,263,423$ \\
1999 & 851,317 & $1,388,102$ & 682,819 & $2,922,238$ \\
$1995-1999$ & 552,073 & 841,243 & 415,653 & $1,808,969$ \\
1998 & 680,768 & $1,042,420^{\mathrm{a}}$ & $575,997^{\mathrm{a}}$ & $2,299,185^{\mathrm{a}}$ \\
1999 & 851,317 & $1,362,635^{\mathrm{a}}$ & $694,629^{\mathrm{a}}$ & $2,908,581^{\mathrm{a}}$ \\
& & & & \\
\hline
\end{tabular}

a Including Hong Kong.

${ }^{\mathrm{b}}$ Excluding Hong Kong, except as noted.

${ }^{c}$ Excluding Hong Kong Portfolio Investment and Other Investment, except as noted.

Sources: IMF (2000) and earlier issues; United Nations (2000) and earlier issues; Republic of China (2000). 


\section{Appendix Table 2. Sources of Direct Investment Outflows}

(Millions of U.S. Dollars)

\begin{tabular}{crrrrr}
\hline Period & $\begin{array}{r}\text { United } \\
\text { States }\end{array}$ & Japan & Europe & $\begin{array}{c}\text { Developing } \\
\text { Asia }\end{array}$ & $\begin{array}{c}\text { Latin } \\
\text { America }\end{array}$ \\
\hline & & & & & \\
1990 & 29,951 & 48,050 & 139,955 & 17,000 & 1,067 \\
1991 & 31,378 & 31,487 & 114,490 & 9,837 & 1,357 \\
1992 & 48,730 & 17,390 & 113,020 & 18,415 & 1,913 \\
1993 & 83,951 & 13,834 & 103,586 & 30,728 & 2,759 \\
1994 & 80,167 & 18,089 & 134,564 & 35,444 & 3,475 \\
$1990-94$ & 54,835 & 25,770 & 121,123 & 22,285 & 2,114 \\
& & & & & \\
1995 & 98,750 & 22,508 & 176,736 & 42,534 & 4,001 \\
1996 & 91,883 & 23,442 & 208,355 & 48,147 & 3,194 \\
1997 & 105,017 & 26,059 & 249,122 & 49,879 & 7,988 \\
1998 & 146,053 & 24,625 & 435,645 & 30,490 & 8,499 \\
1999 & 150,900 & 22,267 & 610,390 & \\
$1995-99$ & 118,521 & 23,780 & 336,050 & 38,884 & 8,236 \\
& & & & & \\
& & & & & \\
\hline
\end{tabular}

${ }^{\mathrm{a}}$ Excluding Norway

Sources: IMF (2000) and earlier issues; United Nations (2000) and earlier issues; Republic of China (2000). 
Appendix Table 3. Destinations of Direct Investment Inflows (Millions of U.S. Dollars)

\begin{tabular}{crrrrr}
\hline Period & $\begin{array}{r}\text { United } \\
\text { States }\end{array}$ & Japan & Europe & $\begin{array}{c}\text { Developing } \\
\text { Asia }\end{array}$ & $\begin{array}{c}\text { Latin } \\
\text { America }\end{array}$ \\
\hline & & & & & \\
1990 & 47,918 & 1,760 & 104,310 & 21,479 & 7,666 \\
1991 & 22,010 & 1,298 & 84,954 & 22,588 & 11,873 \\
1992 & 20,975 & 2,760 & 88,646 & 28,416 & 14,308 \\
1993 & 51,363 & 119 & 88,195 & 49,847 & 12,940 \\
1994 & 46,121 & 912 & 85,972 & 65,134 & 27,457 \\
$1990-94$ & 37,677 & 1,370 & 90,415 & 37,493 & 14,849 \\
& & & & & \\
1995 & 57,776 & 39 & 138,554 & 70,256 & 28,802 \\
1996 & 86,503 & 200 & 135,882 & 85,247 & 42,434 \\
1997 & 106,035 & 3,200 & 164,505 & 91,677 & 63,026 \\
1998 & 186,315 & 3,268 & 282,211 & 85,757 & 70,201 \\
1999 & 275,535 & 12,308 & 396,612 & \\
$1995-99$ & 142,433 & 3,803 & 223,553 & 83,499 & 87,171 \\
& & & & & \\
\hline
\end{tabular}

${ }^{\mathrm{a}}$ Excluding Norway

Sources: See Appendix Table 2. 


\section{Appendix Table 4. Net Inflows of Direct Investment}

(Millions of U.S. Dollars)

\begin{tabular}{cccccc}
\hline \multirow{2}{*}{ Period } & $\begin{array}{c}\text { United } \\
\text { States }\end{array}$ & Japan & Europe & $\begin{array}{c}\text { Developing } \\
\text { Asia }\end{array}$ & $\begin{array}{c}\text { Latin } \\
\text { America }\end{array}$ \\
\hline & & & & & \\
1990 & 17,967 & $-46,290$ & $-35,645$ & 4,479 & 6,599 \\
1991 & $-9,368$ & $-30,189$ & $-29,536$ & 12,751 & 10,516 \\
1992 & $-27,755$ & $-14,630$ & $-24,374$ & 10,001 & 12,395 \\
1993 & $-32,588$ & $-13,715$ & $-15,391$ & 19,119 & 10,181 \\
1994 & $-34,046$ & $-17,177$ & $-48,592$ & 29,690 & 23,982 \\
$1990-94$ & $-17,158$ & $-24,400$ & $-30,708$ & 15,208 & 12,735 \\
& & & & & \\
1995 & $-40,974$ & $-22,469$ & $-38,182$ & 27,722 & 24,801 \\
1996 & $-5,380$ & $-23,242$ & $-72,473$ & 37,100 & 39,240 \\
1997 & 1,018 & $-22,859$ & $-84,617$ & 41,798 & 55,038 \\
1998 & 40,262 & $-21,357$ & $-153,434$ & 55,267 & 61,702 \\
1999 & 124,635 & $-9,959$ & $-213,778$ & 54,615 & 78,935 \\
$1995-99$ & 23,912 & $-19,977$ & $-112,497$ & 43,300 & 51,943 \\
& & & & & \\
\hline
\end{tabular}

${ }^{\mathrm{a} E x c l u d i n g ~ N o r w a y ~}$

Source: Appendix Tables 2 and 3. 


\section{Appendix Table 5. U.S. Private Investment Abroad, 1976-1999}

(Millions of U.S. Dollars)

\begin{tabular}{|c|c|c|c|c|c|c|c|c|}
\hline \multirow{2}{*}{ Year } & \multicolumn{3}{|c|}{ Direct Investment, Valued at } & \multirow{2}{*}{$\begin{array}{l}\text { Foreign } \\
\text { Securities }\end{array}$} & \multirow{2}{*}{$\begin{array}{c}\text { Other Private } \\
\text { Claims }\end{array}$} & \multirow{2}{*}{$\frac{\text { Total, with D }}{\text { Market }}$} & \multirow{2}{*}{$\frac{\text { irect Investmer }}{\text { Current }}$} & \multirow{2}{*}{$\frac{t \text { Valued at }}{\text { Book }}$} \\
\hline & Market & Current & Book & & & & & \\
\hline 1976 & . & 222,283 & 136,809 & 44,157 & 101,452 & & 367,892 & 282,418 \\
\hline 1977 & . & 246,078 & 145,990 & 49,439 & 114,818 & & 410,335 & 310,247 \\
\hline 1978 & - & 285,005 & 162,727 & 53,384 & 160,201 & & 498,590 & 376,312 \\
\hline 1979 & & 336,301 & 187,858 & 56,769 & 191,520 & & 584,590 & 436,147 \\
\hline 1980 & & 388,072 & 215,375 & 62,454 & 242,295 & & 692,821 & 520,124 \\
\hline 1981 & & 407,804 & 228,348 & 62,142 & 336,260 & & 806,206 & 626,750 \\
\hline 1982 & 226,638 & 374,059 & 207,752 & 74,046 & 439, & 740,667 & 888,088 & 721,781 \\
\hline 1983 & 274,342 & 355,643 & 212,150 & 84,723 & 565,834 & 924,899 & $1,006,200$ & 862,707 \\
\hline 1984 & 270,574 & 348,342 & 218,093 & 88,804 & 575 , & 935,147 & 1,012, & 882,666 \\
\hline 1985 & 386,352 & 371,036 & 238,369 & 119,403 & 589,235 & $1,094,990$ & $1,079,674$ & 947,007 \\
\hline 1986 & 530,074 & 404,818 & 270,472 & 158,123 & 674,730 & $1,362,927$ & $1,237,671$ & $1,103,325$ \\
\hline 1987 & 590,246 & 478,062 & 326,253 & 188,589 & 726,825 & $1,505,660$ & $1,393,476$ & $1,241,667$ \\
\hline 1988 & 692,461 & 513,761 & & & 850,984 & $1,776,294$ & $1,597,594$ & $1,431,012$ \\
\hline 1989 & 832,460 & 553,093 & 381,781 & 314,294 & 948,124 & $2,094,878$ & $1,815,511$ & $1,644,199$ \\
\hline 1990 & 731,762 & 616,655 & 430,521 & 342,313 & 961,002 & $2,035,077$ & $1,919,970$ & $1,733,836$ \\
\hline 1991 & 827,537 & 643,364 & 467,844 & 455,750 & 946,697 & $2,229,984$ & $2,045,811$ & $1,870,291$ \\
\hline 1992 & 798,630 & 663,830 & 502,063 & 515,083 & 922,326 & $2,236,039$ & $2,101,239$ & $1,939,472$ \\
\hline 1993 & $1,027,547$ & 723,526 & 564,283 & 853,528 & 928,267 & $2,809,342$ & $2,505,321$ & $2,346,078$ \\
\hline 1994 & $1,067,803$ & 786,565 & 612,893 & 948,668 & $1,016,098$ & $3,032,569$ & $2,751,331$ & $2,577,659$ \\
\hline 1995 & $1,307,155$ & 885,506 & 699,015 & $1,169,636$ & $1,135,716$ & $3,612,507$ & $3,190,858$ & $3,004,367$ \\
\hline 1996 & $1,526,243$ & 986,536 & 795,195 & $1,467,985$ & $1,307,489$ & $4,301,717$ & $3,762,010$ & $3,570,669$ \\
\hline 1997 & $1,778,189$ & $1,058,735$ & 871,316 & $1,751,183$ & $1,526,993$ & $5,056,365$ & $4,336,911$ & $4,149,492$ \\
\hline 1998 & $2,173,547$ & $1,207,059$ & $1,014,012$ & $2,052,929$ & $1,586,301$ & $5,812,777$ & $4,846,289$ & $4,653,242$ \\
\hline 1999 & $2,615,532$ & $1,331,187$ & $1,132,622$ & $2,583,386$ & $1,753,811$ & $6,952,729$ & $5,668,384$ & $5,469,819$ \\
\hline
\end{tabular}

Source: Bargas (2000), and Scholl (2000). 
Appendix Table 6. Foreign Non-Official Assets in the United States, 1976-1999 (Millions of U.S. Dollars)

\begin{tabular}{|c|c|c|c|c|c|c|c|c|}
\hline \multirow{2}{*}{ Year } & \multicolumn{3}{|c|}{ Direct Investment, Valued at } & \multirow{2}{*}{$\begin{array}{c}\text { U.S. } \\
\text { Securities }\end{array}$} & \multirow{2}{*}{$\begin{array}{c}\text { Other } \\
\text { Claims }\end{array}$} & \multicolumn{3}{|c|}{ Total, with Direct Investment Valued at } \\
\hline & Market & Current & Book & & & Market & Current & Book \\
\hline 1976 & . & 47,528 & 30,770 & 61,941 & 78,218 & . & 187,687 & 170,929 \\
\hline 1977 & 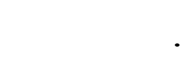 & 55,413 & 34,595 & 58,797 & 85,761 & $\cdot$ & 199,971 & 179,153 \\
\hline 1978 & & 68,976 & 42,471 & 62,464 & 110,307 & & 241,747 & 215,242 \\
\hline 1979 & & 88,579 & 54,462 & 72,797 & 148,547 & . & 309,923 & 275,806 \\
\hline 1980 & & 127,105 & 83,046 & 90,227 & 175,574 & & 392,906 & 348,847 \\
\hline 1981 & & 164,623 & 108,714 & 93,590 & 223,262 & & 481,475 & 425,566 \\
\hline 1982 & 130,428 & 184,842 & 124,677 & 118,746 & 286,785 & 535,959 & 590,373 & 530,208 \\
\hline 1983 & 153,318 & 193,708 & 137,061 & 147,657 & 376,837 & 677,812 & 718,202 & 661,555 \\
\hline 1984 & 172,377 & 223,538 & 164,583 & 190,598 & 430,391 & 793,366 & 844,527 & 785,572 \\
\hline 1985 & 219,996 & 247,223 & 184,615 & 295,822 & 487,526 & $1,003,344$ & $1,030,571$ & 967,963 \\
\hline 1986 & 272,966 & 284,701 & 220,414 & 405,881 & 573,797 & $1,252,644$ & $1,264,379$ & $1,200,092$ \\
\hline 1987 & 316,200 & 334,552 & 263,394 & 424,320 & 684,604 & $1,425,124$ & $1,443,476$ & $1,372,318$ \\
\hline 1988 & 391,530 & 401,766 & 314,754 & 493,169 & 791,164 & $1,675,863$ & $1,686,099$ & $1,599,087$ \\
\hline 1989 & 534,734 & 467,886 & 368,924 & 649,405 & 871,337 & $2,055,476$ & $1,988,628$ & $1,889,666$ \\
\hline 1990 & 539,601 & 505,346 & 394,911 & 613,096 & 932,590 & $2,085,287$ & $2,051,032$ & $1,940,597$ \\
\hline 1991 & 669,137 & 533,404 & 419,108 & 716,303 & 947,470 & $2,332,910$ & $2,197,177$ & $2,082,881$ \\
\hline 1992 & 693,177 & 540,270 & 423,131 & 797,186 & 988,175 & $2,478,538$ & $2,325,631$ & $2,208,492$ \\
\hline 1993 & 768,398 & 593,313 & 467,412 & 917,950 & $1,039,919$ & $2,726,267$ & $2,551,182$ & $2,425,281$ \\
\hline 1994 & 757,853 & 617,982 & 480,667 & 975,379 & $1,181,927$ & $2,915,159$ & $2,775,288$ & $2,637,973$ \\
\hline 1995 & $1,005,726$ & 680,066 & 535,553 & $1,329,893$ & $1,284,951$ & $3,620,570$ & $3,294,910$ & $3,150,397$ \\
\hline 1996 & $1,229,118$ & 743,214 & 598,021 & $1,702,023$ & $1,361,821$ & $4,292,962$ & $3,807,058$ & $3,661,865$ \\
\hline 1997 & $1,639,765$ & 825,334 & 689,834 & $2,240,922$ & $1,626,392$ & $5,507,079$ & $4,692,648$ & $4,557,148$ \\
\hline 1998 & $2,190,990$ & 928,645 & 793,748 & $2,742,169$ & $1,682,354$ & $6,615,513$ & $5,353,168$ & $5,218,271$ \\
\hline 1999 & $2,800,736$ & $1,125,214$ & 986,668 & $3,170,044$ & $1,806,944$ & $7,777,724$ & $6,102,202$ & $5,963,656$ \\
\hline
\end{tabular}

Source: Bargas (2000), Scholl (1990) and (2000). 


\section{Appendix Table 7. The Relation (Adjusted R-square) of U.S. Affiliate Sales, Employment, and PP\&E to U.S. Outward FDI Stock Across Countries: Total and 12 Industry Groups}

\begin{tabular}{lccc}
\hline Regression & $\begin{array}{c}\text { Sales } \\
1998\end{array}$ & $\begin{array}{c}\text { Employment } \\
1998\end{array}$ & $\begin{array}{c}\text { PP\&E } \\
1994\end{array}$ \\
\hline All Industries & & & \\
& 0.79 & 0.59 & 0.82 \\
Petroleum & & & \\
Manufacturing & 0.51 & 0.85 & 0.98 \\
$\quad$ Food & 0.91 & 0.85 & 0.88 \\
Chemicals & 0.88 & 0.58 & 0.79 \\
$\quad$ Metals & 0.69 & 0.58 & 0.76 \\
$\quad$ Nonelectrical machinery. & 0.89 & 0.64 & 0.88 \\
$\quad$ Electrical machinery & 0.70 & 0.89 & 0.84 \\
$\quad$ Transportation equipment & 0.46 & 0.51 & 0.72 \\
$\quad$ Other Mfg. & 0.66 & 0.69 & 0.78 \\
Wholesale & 0.96 & 0.79 & 0.85 \\
Finance (excl. Banking) & 0.76 & 0.58 & 0.87 \\
Services & 0.91 & 0.78 & 0.64 \\
Other Industries & 0.47 & 0.37 & 0.70 \\
& & & 0.87 \\
\hline
\end{tabular}

Source:

Outward FDI Stock: U.S. Department of Commerce (2000d).

Affiliate Sales and Employment: U.S. Department of Commerce (2000c).

Affiliate PP\&E: U.S. Department of Commerce (1998a). 
Appendix Table 8. The Relation (Adjusted R-Square) of U.S. Affiliate Sales, Employment, and PP\&E to the U.S. Outward FDI Stock Across Countries and Industries

\begin{tabular}{lcc}
\hline Regression & Adj. $\mathrm{R}^{2}$ & No. of Obs. \\
\hline & & \\
Sales (1998) & 63 Industry Groups X 9 Countries \\
\cline { 2 - 3 } Employment (1998) & 0.1020 & 304 \\
PP\&E (1994) & 0.0167 & 442 \\
& 0.0411 & 196 \\
Sales (1998) & & \\
Employment (1998) & 0.2915 & 419 \\
PP\&E (1994) & 0.0980 & 579 \\
& 0.1551 & 339 \\
\hline
\end{tabular}

Source: See Appendix Table 7. 
Appendix Table 9. The Relation (Adjusted R-Square) of Changes in U.S. Affiliate Sales, Employment, and PP\&E to Changes in U.S. Outward FDI Stock Across Countries by 12 Industry Groups

\begin{tabular}{|c|c|c|c|c|}
\hline \multirow{2}{*}{ Regression } & \multicolumn{2}{|c|}{ Absolute Changes } & \multicolumn{2}{|c|}{ Relative Changes } \\
\hline & Adj. $R^{2}$ & No. of Obs. & Adj. $R^{2}$ & No. of Obs. \\
\hline & \multicolumn{4}{|c|}{ Sales (1982-98) } \\
\hline All Industries & 0.7282 & 48 & 0.3910 & 48 \\
\hline Petroleum & -0.0617 & 18 & 0.1332 & 18 \\
\hline Manufacturing & 0.8371 & 41 & 0.4741 & 41 \\
\hline Food & 0.7925 & 17 & -0.0593 & 13 \\
\hline Chemicals & 0.5335 & 32 & 0.0897 & 31 \\
\hline Metals & 0.7540 & 20 & 0.4941 & 17 \\
\hline Nonelectrical mach. & 0.8944 & 31 & 0.5125 & 14 \\
\hline Electrical machinery & 0.6513 & 26 & 0.1779 & 20 \\
\hline Transportation equip. & 0.4088 & 19 & 0.0765 & 6 \\
\hline Other Mfg. & 0.4869 & 7 & 0.0985 & 6 \\
\hline Wholesale & 0.8013 & 26 & 0.7974 & 26 \\
\hline Finance (excl. Banking) & 0.6707 & 19 & 0.1398 & 19 \\
\hline Services & 0.9175 & 31 & 0.4073 & 30 \\
\hline \multirow[t]{2}{*}{ Other Industries } & 0.0999 & 5 & 0.4838 & 4 \\
\hline & \multicolumn{4}{|c|}{ PP\&E (1982-94) } \\
\hline All Industries & 0.7166 & 49 & 0.1256 & 49 \\
\hline Petroleum & 0.9610 & 12 & 0.1605 & 13 \\
\hline Manufacturing & 0.8092 & 38 & 0.2032 & 37 \\
\hline Food & 0.4990 & 22 & 0.9732 & 16 \\
\hline Food (w/o Turkey) & & & 0.0408 & 15 \\
\hline Chemicals & 0.6422 & 32 & 0.3400 & 30 \\
\hline Metals & 0.4954 & 18 & -0.0760 & 14 \\
\hline Nonelec. & 0.6329 & 23 & 0.3290 & 12 \\
\hline Electric & 0.6727 & 22 & 0.5593 & 15 \\
\hline Transportation & 0.7494 & 18 & 0.8585 & 3 \\
\hline Other Mfg. & 0.7709 & 11 & 0.8574 & 9 \\
\hline Wholesale & 0.8765 & 22 & 0.8161 & 22 \\
\hline Finance (excl. Banking) & 0.6383 & 15 & 0.0262 & 13 \\
\hline Services & 0.5896 & 25 & 0.7521 & 23 \\
\hline Other Industries & 0.7436 & 6 & -0.2390 & 6 \\
\hline
\end{tabular}


(Continue Appendix Table 9)

\begin{tabular}{lccccc}
\hline \multirow{2}{*}{ Regression } & \multicolumn{2}{c}{ Absolute Changes } & & \multicolumn{2}{c}{ Relative Changes } \\
\cline { 2 - 3 } \cline { 5 - 6 } & Adj. $\mathrm{R}^{2}$ & No. of Obs. & & Adj. $\mathrm{R}^{2}$ & No. of Obs. \\
\hline & \multicolumn{4}{c}{ Employment } & $(1982-98)$ \\
All Industries & 0.1335 & 52 & 0.2326 & 52 \\
Petroleum & -0.0250 & 34 & & 0.0066 & 33 \\
Manufacturing & 0.3219 & 49 & & 0.5490 & 48 \\
$\quad$ Food & 0.0210 & 39 & & 0.5408 & 32 \\
Chemicals & 0.0260 & 40 & & 0.7148 & 39 \\
Metals & -0.0211 & 29 & & 0.2217 & 25 \\
Nonelec. & -0.0051 & 40 & & -0.0500 & 22 \\
Electric & -0.0208 & 33 & & -0.0161 & 26 \\
Transportation & -0.0301 & 32 & & 0.1265 & 15 \\
Other Mfg. & 0.3170 & 19 & & -0.0434 & 17 \\
Wholesale & 0.1381 & 35 & & 0.3490 & 35 \\
Finance (excl. Banking) & 0.4273 & 32 & & 0.1220 & 28 \\
Services & 0.7556 & 40 & & 0.0202 & 39 \\
Other Industries & -0.0013 & 17 & & -0.0633 & 16 \\
& & & & \\
\hline
\end{tabular}

Source:

Outward FDI Stock: U.S. Department of Commerce (2000d).

Affiliate Sales and Employment: U.S. Department of Commerce (1985) and (2000c).

Affiliate PP\&E: U.S. Department of Commerce (1985) and (1998a). 
Appendix Table 10. The Relation (Adjusted R-Square) of Changes in U.S. Affiliate Sales, Employment, and PP\&E to Changes in U.S. Outward FDI Stock Across 52 Countries and 12 Industry Groups

\begin{tabular}{lcc}
\hline Regression & Adj. $\mathrm{R}^{2}$ & No. of Obs. \\
\hline & \multicolumn{2}{c}{ Absolute Changes } \\
\cline { 2 - 3 } Sales (1982-98) & 0.2705 & 251 \\
PP\&E (1982-94) & 0.0605 & 227 \\
Employment (1982-98) & 0.0257 & 390 \\
& \multicolumn{2}{c}{ Relative Changes } \\
Sales (1982-98) & 0.1212 & 204 \\
PP\&E (1982-94) & 0.2788 & 176 \\
Employment (1982-98) & 0.1808 & 327 \\
& & \\
\hline
\end{tabular}

Source: See Appendix Table 9. 